\title{
A magyar költségvetés kamatmegtakarítása EU-s összevetésben 2013 és 2019 között*
}

\author{
Kicsák Gergely - Benkő Dávid - Végh Noémi
}

A tanulmányban összehasonlítjuk az állami kamatkiadások csökkenését Magyarországon és az Európai Unió más tagállamaiban. 2013 és 2019 között az egész EU-ban csökkentek az állami kamatkiadások, és a csökkenés Magyarországon volt a második legnagyobb mértékü, ahol a GDP 4,5 százalékáról 2,3 százalékra mérséklödött az állami kamatfizetés. Annak érdekében, hogy megtudjuk, mi okozta ezt az EU-s összevetésben is kedvezö folyamatot, a kamatkiadás változását három fö tényezöre bontottuk fel: a hozam- és kamathatásra, az adósságráta változásának hatására és a devizaadósság hatására. Elemzésünk szerint a hazai kiadáscsökkenést döntö részben, mintegy 80 százalékban a hazai hozamok mérséklödése, kisebb részben, mintegy 18 százalékban pedig az adósságráta csökkenése okozta. Alacsonyabb devizaadósság-arány mellett még nagyobb lehetett volna Magyarországon a kamatkiadások mérséklődése.

Journal of Economic Literature (JEL) kódok: E42, H50, H62, H63

Kulcsszavak: államháztartás, kamatkiadások, monetáris politika

\section{Bevezetés}

Tanulmányunkban megvizsgáltuk az államháztartás eredményszemléletü kamatkiadásait az Európai Unióban 2013 és 2019 között. A vizsgálat célja azoknak a tényezőknek a feltárása volt, amelyek az egyes országokban hozzájárultak a kamatkiadások csökkenéséhez. Emellett a magyar kiadáscsökkenést nemzetközi öszszehasonlításban kívántuk vizsgálni. A kamatkiadások csökkenése az időszak során Magyarországon volt a második legmagasabb az Európai Unió tagországai között, és elérte a GDP 2,2 százalékát. Ahhoz, hogy megértsük a kedvező pozíció mögött álló okokat, érdemes megvizsgálni, hogy mi volt a csökkenés fő mozgatórugója. A Kicsák (2017) tanulmányban alkalmazott adósságdekompozícióhoz hasonló metódus fel-

\footnotetext{
* A jelen kiadványban megjelenő írások a szerzők nézeteit tartalmazzák, ami nem feltétlenül egyezik a Magyar
} Nemzeti Bank hivatalos álláspontjával.

Kicsák Gergely a Magyar Nemzeti Bank föosztályvezetője. E-mail: kicsakg@mnb.hu Benkő Dávid a Magyar Nemzeti Bank közgazdasági elemzője.E-mail: benkod@mnb.hu Végh Noémi a Magyar Nemzeti Bank elemzője. E-mail: veghn@mnb.hu

A szerzők köszönetet mondanak Baksay Gergelynek, Csomós Balázsnak, P. Kiss Gábornak és Babos Dánielnek a tanulmány elkészítéséhez nyújtott hasznos észrevételeikért. Az esetleges hibákért kizárólag a szerzőket terheli felelősség.

A magyar nyelvű kézirat első változata 2020. június 12-én érkezett szerkesztőségünkbe.

DOI: http://doi.org/10.25201/HSZ.19.4.526 
használásával valamennyi uniós tagország esetében három fő tényezőre bontottuk fel a kamatkiadások évről-évre bekövetkező változását (Melléklet 1. táblázat). Ez a három legfontosabb tényező a hozam- és kamathatás, az adósságráta változásának hatása és a devizaadósság hatása. Eredményeink azt mutatják, hogy a hozam- és kamathatás a legerősebb magyarázó erővel bíró tényező, ami hazánkban mintegy 80 százalékban magyarázza a kamatkiadások csökkenését 2013 és 2019 között, míg az Európai Unió átlagában a kamatkiadások mérséklődését közel 100 százalékban a hozamcsökkenés okozta. Ennek alapján kijelenthető, hogy az elmúlt években a jegybanki programok, a kedvező hazai makrogazdasági folyamatok, a fegyelmezett költségvetési politika és a nemzetközi likviditásbőség hatására bekövetkező állampapírpiaci hozamcsökkenésnek köszönhető az állami kamatkiadás-csökkenés. Az adósságráta mérséklődése mintegy 18 százalékban magyarázza a GDP-arányos kamatmegtakarítást, ami alacsonyabb devizaadóssággal még nagyobb lehetett volna.

A 2. fejezetben áttekintjük a kapcsolódó szakirodalmi előzményeket. Ezt követően a 3. fejezetben bemutatjuk a kamatkiadások alakulását hazánkban és az EU-ban, valamint az éves és kumulált kamatmegtakarítást 2013-hoz képest. A 4. fejezet a kamatkiadás csökkenésének okait elemző módszertant mutatja be röviden, míg az eredmények részletes ismertetése az 5 . fejezettöl kezdődik, ahol megvizsgáljuk a kamatkiadást befolyásoló három tényező hatásait nemzetközi összehasonlításban. Az ezt követő fejezetekben egyenként is bemutatjuk és az Európai Unión belül kontextusba helyezzük a három fő hatást. Az utolsó fejezet a következtetéseinket tartalmazza.

\section{Szakirodalmi áttekintés}

Tanulmányunk egyik alapját Kicsák (2017) elemzése képezi, amely a kamatkiadások alakulását vizsgálta Magyarországon 2000 és 2015 között, elsősorban a 2013 és 2015 között megfigyelhető hozam- és kamatkiadás-csökkenés kapcsolatát elemezve. A tanulmány megállapítja, hogy 2008 és 2015 között a régió országai közül Magyarországon csökkentek a legnagyobb mértékben, mintegy 0,8 százalékponttal a GDP-arányos kamatkiadások. A csökkenést lehetővé tevő kedvező hozamkörnyezet kialakulását már 2013-tól érdemben támogatták a jegybanki programok, kiemelten a kamatcsökkentések, valamint a hazánk külső sérülékenységét mérséklö Önfinanszírozási Program. Az elemzés a jelen tanulmányban használt módszertanhoz hasonló vizsgálat alapján a hozamváltozást tekinti a kamatkiadások csökkenésében legnagyobb szerepet játszó hatásnak, amelyet az adósságráta változása és a devizaadósság hatása követ. Aktuális tanulmányunkban nemcsak Magyarországra, hanem az Európai Unió valamennyi tagországára elvégeztük a kamatkiadások tényezőkre bontását, és a hozamváltozást kibővítettük a nem piaci hitelekkel, hogy az IMF és az Európai Stabilitási Mechanizmus (ESM) segélyhiteleinek hatását is azonosítani 
tudjuk, amivel várakozásunk szerint sikerül csökkenteni a Kicsák (2017) tanulmányban be nem kategorizált egyéb hatások mértékét.

A korábbi előzmények közül Izák (2009) a posztszocialista államok elsődleges egyenlegének és államadósságának alakulását vizsgálta, valamint több fiskális változó mellett a reálkamatok adóssághatását is bemutatta. A tanulmány megállapítja, hogy Lengyelországon kívül a többi posztszocialista országban megfelelően tudták stabilizálni a GDP-arányos adósságot negatív elsődleges egyenleg mellett is. Lengyelországban ugyanakkor a stabilizáció a GDP-növekedést 1999 és 2006 között meghaladó reálkamat miatt csak szufficites elsődleges egyenleggel volt lehetséges.

A fiskális politika fenntarthatóságának elemzése sok esetben az államadósság fenntarthatóságából indul ki. A fiskális fenntarthatóság szakirodalmán belül Blanchard (1990) tanulmánya alapvetőnek számít, melyben a szerző a költségvetési korlátból indul ki. A definíció szerint a jövőbeli költségvetési többletek jelenértékének meg kell egyeznie a jelenlegi adósság szintjével. Ebben az esetben azonban arra a kérdésre nem kapunk választ, hogy a jelenlegi költségvetési politika fenntartható-e, hiszen egy későbbi kiigazítás esetén is teljesülhet a fenti kritérium, ahogy azt Tóth $G$. (2011) megjegyzi. Tóth $G$. tanulmányában a magyar államadósság fenntarthatóságát elemezve az adósságdinamika, valamint annak okai alapján három gazdaságpolitikai szakaszra osztotta az 1999 és 2010 közötti időszakot. Az 1999 és 2001 közötti időszakban a gazdasági növekedés és az elsődleges egyenleg következtében közel 10 százalékponttal csökkent az államadósság. A 2002 és 2006 közötti, 13 százalékpontot meghaladó adósságráta-emelkedést elsősorban a negatív elsődleges egyenleg, valamint a reálkamatok magas szintje okozta, amit csak részben ellensúlyozott a gazdasági növekedés. A 2008-as világgazdasági válság első éveit is magában foglaló harmadik időszak (2007-2010) végére az adósság további, közel 15 százalékpontos emelkedéssel meghaladta a GDP 80 százalékát. Az emelkedés ráadásul semleges elsődleges egyenleghatás mellett következett be, főként a gazdasági visszaesés és a magas reálkamatok következtében.

Tóth G. (2014) a közpénzügyek fenntarthatóságát elemezte az Európai Unió 27 tagországának adatai alapján. A szerző múltbeli adatokon tesztelte, hogy öt különböző módszer mennyire hatékonyan jelezte előre a költségvetés fenntarthatatlanságát. A tanulmány fő megállapítása, hogy a módszerek előrejelzési képessége korlátozott (ez alól az elsődleges költségvetési rés kivételt képez), aminek fő oka a fiskális politikán kívüli változók hatása lehet. A szerző felhívta továbbá a figyelmet arra, hogy az egyes előrejelzések eredménye nagyban függ az ökonometriai módszer megválasztásától is.

Az adósság fenntarthatóságával kapcsolatos elemzések az adósság szintje mellett annak szerkezetét és az adósságkezelést is fontosnak tartják. Panizza (2008) írásában kiemelte, hogy a teljes államadósság mellett a külső és belső adósság 
arányának alakulása is fontos. Ezenkívül hangsúlyozta az adósság struktúrájának, szerkezetének jelentőségét is. Guscina (2008) szerint fontos a politikai stabilitás, a megfelelő intézményi háttér és a biztos makrogazdasági környezet, ugyanis ezek teremtik meg a belföldi állampapírpiac fejlődésének alapjait. Ennek a legfontosabb következménye a hosszabb futamidejü, hazai fizetőeszközben kibocsátott kötvények iránti kereslet növekedése, ami lehetőséget biztosít az államadósság átlagos hátralévő futamidejének hosszabbítására. A futamidő növelésének következménye az éves bruttó finanszírozási igény csökkenése, ami érdemben csökkenti az ország finanszírozási kockázatát. Das és társai (2010) tanulmányukban az adósság szintje, az adósságkezelés és a pénzügyi stabilitás közötti kapcsolatot vizsgálták. A szerzők kifejtik, hogy az adósságkezelés visszavásárlásokkal, csereaukciókkal és derivatív ügyletekkel tudja mérsékelni a kockázatokat, továbbá célszerű diverzifikálni a befektetői bázist, és változó kamatozású kötvényeket kibocsátani.

Hemming és Petrie (2000) tanulmányukban egy több változóból álló keretrendszert dolgoztak ki a fiskális sérülékenység mérésére. Elemzésükben - hét kategóriába sorolva az indikátorokat - szerepelnek a kezdeti fiskális pozíciót leíró változók (pl. hiány, államadósság), kiadási és bevételi indikátorok (pl. transzferek GDP-arányos értéke, bevételek eloszlása). Emellett figyelembe vették az államadósságra vonatkozó rövid (pl. az adósság devizaaránya) és hosszú távú kockázatot jellemző mutatókat (pl. az adósság változása a következő öt évben). A szerzők elemzésükbe bevontak a költségvetés végrehajtását jellemző változókat, illetve a kormányzat hatékonyságára vonatkozó indexeket, így intézményi jellemzőket is szerepeltettek a tanulmányukban.

Baksay et al. (2012) az adósságfinanszírozás és a devizatartalék kapcsolatát vizsgálta, és megállapította, hogy bár a devizakibocsátás érdemben hozzájárulhat a devizatartalék növekedéséhez, és látszólag kedvezőbb a kamatköltsége az állam számára, a jegybankkal konszolidáltan már korántsem kedvező a kép. A tanulmány szerint az akkori körülmények között a devizaadósság alacsonyabb kamatai miatti megtakarítást ellensúlyozza a jegybanknál jelentkező nettó kamatveszteség, amelyet a devizakonverzióból létrejövő alapkamaton sterilizált addicionális likviditás, valamint az alacsonyabb kamaton befektetett devizatartalékba kerülő deviza kamatkülönbsége okoz. Így a devizaadósság esetén az államnál jelentkező kamatmegtakarítással a jegybanki eredmény romlása áll szemben.

Turner - Spinelli (2012) az államadósság kamata és a gazdasági növekedés különbségét $(r-g)$ elemezte a költségvetési fenntarthatóság szempontjából. Megállapította, hogy az 1980-as, 1990-es évekhez képest a 2000-es években ez a differencia kifejezetten alacsony volt, ami részben az infláció alacsony volatilitásának, valamint a hiteles és alacsony inflációs céloknak köszönhető. A tanulmány szerint egy adott elsődleges egyenleg és kezdeti adósságráta esetén minél nagyobb az eltérés a ka- 
matok és a növekedés között, annál nagyobb lesz a GDP-arányos államadósság változása.

A Bundesbank (2017) az eurozóna tagállamainak, azon belül Németországnak a kamatkiadásait vizsgálta. Megállapította, hogy az euroövezetben a kamatmegtakarítások mértéke 2008 és 2017 között megközelítette a GDP 9 százalékát. A jelenlegi elemzésünk szempontjából kiemelten releváns eredmény, hogy a kamatkiadások alakulását a tanulmány szerint is elsősorban a hozamok változása határozta meg. Németországban a GDP-arányos kamatkiadások a GDP 3,5 százalékáról 1,5 százalék alá mérséklődtek 1995 és 2016 között, amit az emelkedő adósság ellenére a jelentős mértékű, 5 százalékpontos hozamcsökkenés tett lehetővé. Az eurozóna több államában is megfigyelhető volt, hogy míg az adósság 2000 és 2015 között emelkedett, az állami kamatkiadások jelentősen mérséklődtek.

Lentner (2015) a hazai állampénzügyi rendszer 2008-as válság utáni megújulását vizsgálta. Megállapította, hogy a 2010-től elindult tehermegosztásra és állami gazdaságbefolyásolásra építő irányítási modell, majd 2013-tól a nem hagyományos monetáris politika támogatta a növekedést és a pénzügyi rendszer stabilizációját. A finanszírozási költségek csökkentésében kiemelkedő szerepet játszott a Magyar Nemzeti Bank 2012-ben megkezdett kamatcsökkentési ciklusa, az azt követően elindított Növekedési Hitelprogramja, valamint az Önfinanszírozási Programja. A hazai monetáris politikai környezetet és költségvetési folyamatokat vizsgálva Matolcsy (2019) hasonló következtetésre jutott. Tanulmányában kifejtette, hogy a költségvetési hiány konszolidációja és a gazdasági növekedés ösztönzése az államadósság csökkenése irányába hatott, továbbá 2013-tól a monetáris lazítás az állampapírpiaci hozamok mérséklődésén keresztül kedvező hatást gyakorolt az államháztartás kamatkiadásaira.

\section{A kamatkiadások változása és a változás fő okai nemzetközi összevetésben}

A magyar állam (lásd részletesebben Kicsák 2017) kamatkiadása a GDP 4,5 százalékáról 2,3 százalékra csökkent 2013 és 2019 között, ami a második legnagyobb csökkenés az EU-ban. Azaz a hazai éves kamatkiadás közel a felére mérséklődött az időszak alatt, ami érdemben hozzájárult az államadósság csökkenéséhez is. Eredményeink szerint a hozam- és kamathatás több mint 80 százalékban, az adósságráta hatása pedig mintegy 18 százalékban magyarázza a kamatkiadások csökkenését Magyarországon, amely alacsonyabb devizaadósságszint mellett még nagyobb lett volna. A kamatkiadás csökkenése ráadásul úgy valósult meg hazánkban, hogy közben az adósságfinanszírozáson belüli belföldi források aránya érdemben nőni tudott.

A magyar költségvetés kamatkiadása jelentősen, közel felére csökkent 2013 és 2019 között, aminek következtében az állami kamatmegtakarítás a GDP 2,2 százalékát tette ki 2019-ben (1. ábra). A kamatkiadások csökkenését 2013-tól egyszerre támogatta 
a két fő gazdaságpolitikai ág összehangolt múködése. Az önálló monetáris politika, illetve a jegybank innovativ és célzott eszközei lehetőséget teremtettek arra, hogy a költségvetési politikával összhangban eredményesen támogassák a fenntartható államháztartási folyamatok kialakítását (Matolcsy - Palotai 2018). Az összhang kedvező hatása a gazdaság számos más területén jelentkező eredmények mellett az állami kamatkiadások csökkenésében is tetten érhető. Mint később részletesen is látni fogjuk, az érdemi megtakarítást leginkább a hozamcsökkenés, valamint részben az adósságráta csökkenése magyarázza, amelyet visszacsatolásképpen, folyamatosan támogatnak az alacsonyabb kamatkiadások.

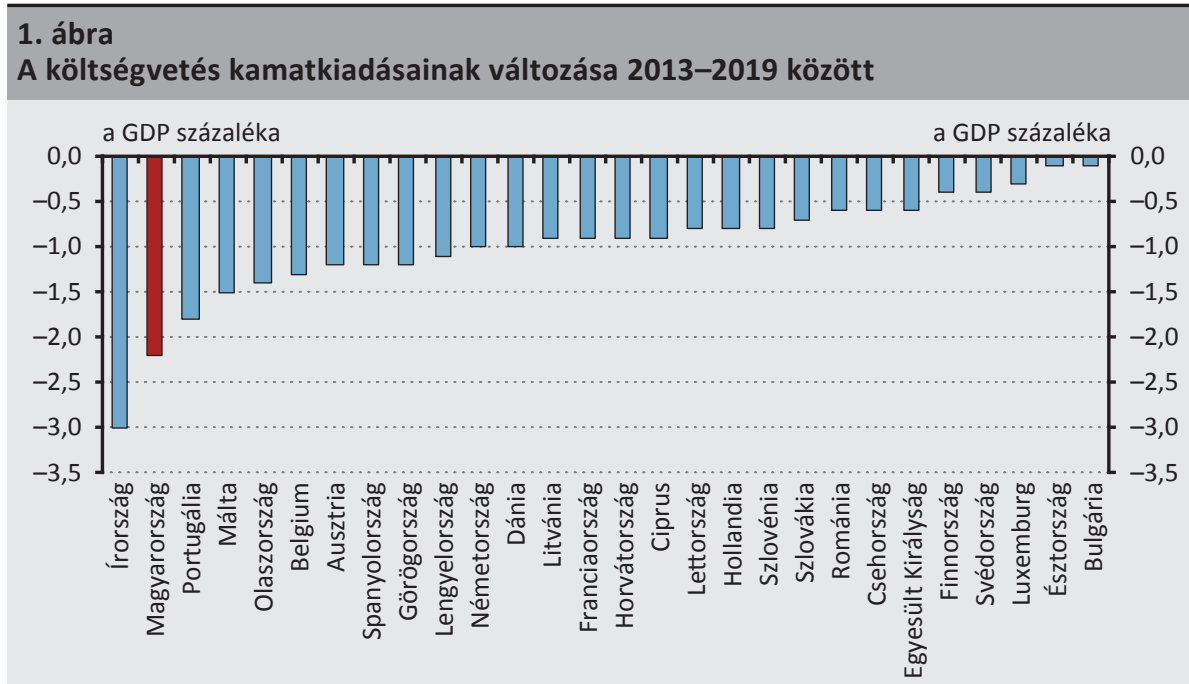

Forrás: Eurostat

A hazai kiadáscsökkenésnél csak az ír mérséklődés volt nagyobb, amit elősorban az ír GDP-növekedés okozott. Írországban számos nemzetközi nagyvállalat - főként informatikai óriáscégek - jegyezte be székhelyét a kedvező adózási kondíciók miatt. Főként a nagyvállalatok betelepülésének, részben pedig az ír gazdaság saját bővülésének köszönhető, hogy 2015-ben az ír GDP több mint 25 százalékkal növekedett, valamint a 2013-2019-es időszak során további 3 alkalommal is 8 százalék feletti bővülést mutatott.

Szintén érdekes példa a harmadik legnagyobb csökkenést mutató Portugália, valamint Görögország esete, ahol a kamatkiadások jelentős csökkenését az EU-IMF mentőcsomag kedvező kamatozású hitelei eredményezték. Mivel a görög államadósságon belül alacsony a piaci kamatozású elemek aránya, így a piaci hozamok kiugró ütemú mérséklődésének kisebb hatása volt. A nemzetközi hitelek alacsony kamatozásának hatását a GDP-arányos kamatkiadások szempontjából részben ellensúlyozta 
a mentőcsomagok feltételeként megállapított költségvetési kiigazítás keresletszúkítő hatása, ami érdemben hozzájárult ahhoz, hogy a görög gazdaság teljesítménye reálértéken a vizsgált időszakon belül 3 évben is csökkent.

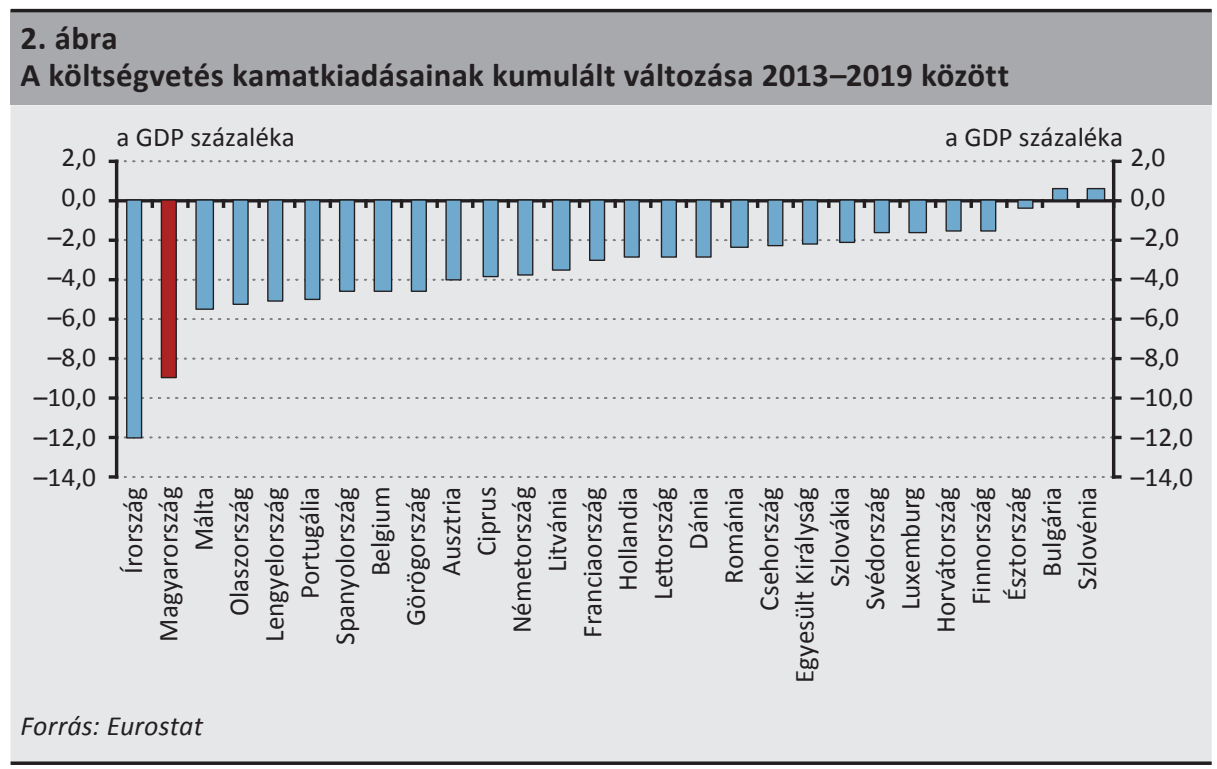

Az állami kamatkiadásokban jelentkező megtakarítás hazánkban elérte a GDP 9 százalékát, melynél csak az ír megtakarítás volt nagyobb: a GDP 12 százaléka (2. ábra). A kumulált megtakarítás jól mutatja azt a pozitív adósságspirált, amely hazánk példáján keresztül is látszik. E pozitív spirál lényege, hogy a kamatkiadások csökkenése érdemben hozzájárul az államadósság mérséklődéséhez, majd az adósságcsökkenés visszahat a kamatkiadásokra, tovább csökkentve az adósságszolgálat költségeit. A magyar gazdaságpolitika 2010 utáni modellváltása, valamint a jegybank kamatcsökkentési ciklusa és önfinanszírozási programja a hozamok mérséklődésén, valamint az államadósság tartós csökkentésén keresztül hozzájárult a költségvetés fenntarthatóságának érdemi javulásához (Kicsák 2015).

A kiemelt példák megmutatják, hogy az egyes országok esetében eltérő folyamatok voltak a kiadásváltozás fő mozgatórugói. Azért, hogy ezeket a mozgatórugókat azonosítani tudjuk, és hogy megvizsgáljuk, mi okozta Magyarországon a kamatkiadások nemzetközi viszonylatban is számottevő csökkenését, a kamatkiadás változását három fö tényezőre bontottuk fel: a hozam- és kamathatásra, az adósságráta változásának hatására és a devizaadósság hatására (3. ábra). 


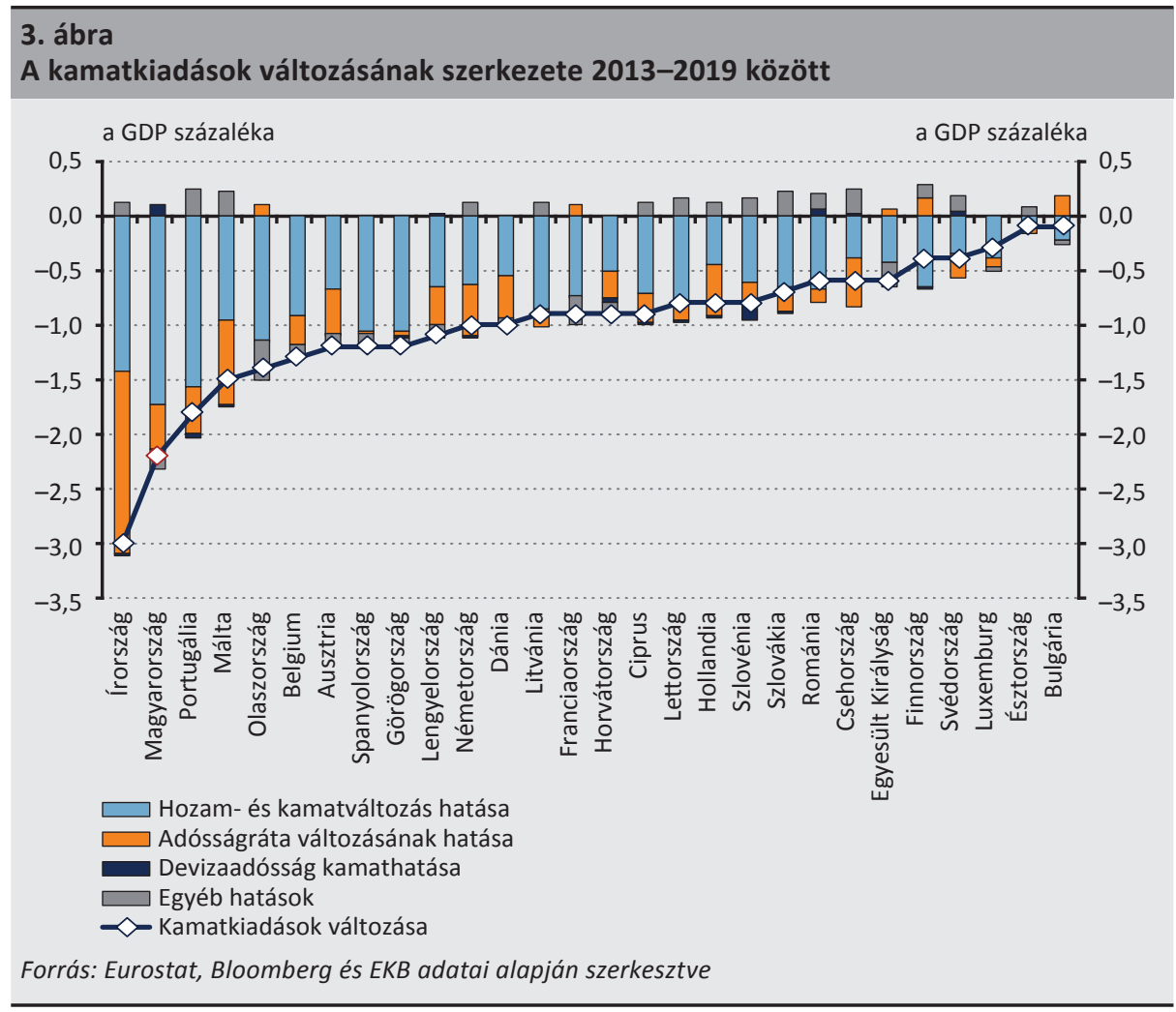

A felbontás alapján megállapítható, hogy az EU-tagországokban a hozam- és kamatváltozás volt a legerősebb hatással a kamatkiadások csökkenésére, ami az Európát (és az egész világgazdaságot) jellemző globális konjunktúra, likviditásbőség és laza monetáris kondíciók következménye. Az Európai Központi Bank (EKB) a 2008-as gazdasági válság kitörésekor gyors kamatcsökkentésekkel reagált, ugyanakkor csak 2010-ben kezdte meg a mediterrán országok kamatfelárainak csökkentését célzó államkötvény-vásárlásokat (Csutiné et al. 2017). A program méretéből adódóan azonban csak a felárak emelkedését tudta megállítani, tartós hozamcsökkenés nem történt, ami hozzájárult a déli országokban a magas államadósság-ráták fennmaradásához (Matolcsy - Palotai 2018). Több ország esetében az is megfigyelhetö, hogy a hozamok és kamatok változásának kiadáscsökkentő hatása az adósságráta közel semleges, vagy akár a kiadásokat növelő hatásával párosul, vagyis az alacsony kamatkörnyezet ebben az időszakban elfedte az adósságráta stagnálásából, illetve növekedéséből fakadó kedvezőtlen hatásokat. Ez a későbbiekben kockázatot jelenthet, ugyanis ha a hozamszintek növekedése bekövetkezik, akkor azokban az országokban, amelyek nem tudták érdemben csökkenteni 2013-2019 között az államadósság-rátájukat, a kamatkiadások emelkedése és ezzel együtt a költségvetési egyenleg hirtelen romlása valósulhat meg. Ez negatív adósságspirálba taszíthatja 
ezeket az országokat, valamint a válságkezelés is sokkal nagyobb terhet ró a költségvetésre és annak fenntarthatóságára ezekben az államokban. Hazánk esetében az elmúlt évek folyamatos és tartós adósságcsökkenésének köszönhetően nem jelentkezik ilyen kockázat.

\section{A kamatváltozás felbontásához alkalmazott módszertan egyszerüsített bemutatása}

Elemzésünkben úgy próbáltuk meg a kamatkiadások évenkénti változását megvizsgálni, hogy a változáson belül - az adósságdekompozíciós módszertanokat alapul véve - három makrogazdasági tényező hatását külön-külön ragadjuk meg. A felbontást Kicsák (2017) alapján végeztük, ugyanakkor az ott bemutatott módszer eszköztárát frissítettük, több ponton finomhangoltuk és kibővítettük, hogy az néhány egyszerűsítés mellett alkalmas legyen az EU valamennyi országának vizsgálatára.

A hozam- és kamatváltozás hatását az egyes országokra elérhető benchmark hozamok felhasználásával végeztük. Ha a hozam ( $r$ ) változását a hazai devizában denominált adósságra $\left(D^{D O M}\right)$ kiszámoljuk, és azt a GDP-arányában kifejezzük, akkor elméletben a hozamváltozás adott évi hatását kapjuk meg (eff $\Delta r)$. Az állam adósságára azonban nem fizeti rögtön az adott évi hozamot, ugyanis az egyes adósságelemek eltérő idő alatt árazódnak át az új hozamszintre. Emiatt a hozamváltozást korrigálni kell ezzel az átárazódási idővel. Az átárazódás üteme az egyes országokra jellemző adósságszerkezet miatt országonként és különböző időpontokban is más és más lehet, azonban adathiány miatti egyszerűsítés céljából a magyar átárazódási ütemet vettük alapul. Az átárazódás ütemére emiatt érzékenységvizsgálatot végeztünk, amely szerint más ütemet felhasználva sem jelentkezne érdemi különbség az eredményekben. Figyelembe vettük azt is, hogy az EU-IMF mentőcsomagok szintén hatnak a kamatkiadásokra, ami így részben elfedi ezekben az országokban a hozamváltozás hatását. A hozamhatás számszerūsítése során frissítettük, illetve a jelenlegi időszakra és országcsoportra parametrizáltuk a Kicsák (2017) tanulmányban szereplő képletet, újrabecsülve az átárazódási ütemhez kapcsolódó súlyokat.

$$
e f f_{\Delta r}=\sum_{i=0}^{6} \frac{\left(r_{t-i}-r_{t-i-1}\right) \cdot D_{t-i}^{D O M}}{G D P_{t-i}^{n o m}} \cdot \frac{x_{i+1}}{100}
$$

ahol $x$ az átárazódás mértéke az egyes években és $x=[33,13,11,10,10,9,14]$.

Az adósságráta változásának hatása (eff $\left.\Delta D_{-} r a t e\right)$ az adott évi és a megelőző évi adósságráta különbözetének, valamint az adott évi implicit kamatnak $\left(I_{t}^{i m p}\right)$ a szorzata, az adott évi implicit kamat kiszámítása pedig az adott évi nominális kamatkiadásnak és a megelőző évi nominális adósságnak a hányadosa. Az adósságráta változását a Kicsák (2017) tanulmányhoz képest újragondoltuk, egyszerűsítettük, több ponton frissítettük, és valamennyi EU-országra alkalmazhatóvá tettük. Elemzésünkben 
az államadósság-ráta változásának hatását egy lépésben becsüljük meg, szemben a tanulmánnyal, ahol három tényezőre (reálnövekedés, GDP-deflátor, nominális adósságdinamika) bontva került becslésre ez a hatás. Véleményünk szerint ugyanis nem szükséges egy hatás becsléséhez 3 részre bontani az adósságráta változását.

$$
\begin{gathered}
\text { eff } f_{\Delta D_{-} \text {rate }}=\left(D_{t}^{\text {rate }}-D_{t-1}^{\text {rate }}\right) \cdot \frac{I_{t}^{\text {imp }}}{D_{t-1}^{\text {nom }}}, \\
\text { ahol } I_{t}^{i m p}=\frac{I_{t}^{\text {nom }}}{D_{t-1}^{\text {nom }} .}
\end{gathered}
$$

A devizaadósság kamathatása (eff $F_{F X_{D}}$ ) úgy számítható ki, hogy a tárgyévi devizaadósság $\left(D_{t}^{F X}\right)$ adott évi és megelőző évi árfolyamon $\left(X_{t}\right.$ és $\left.X_{t-1}\right)$ számított értékének különbségét megszorozzuk az implicit kamattal $\left(I_{t}^{i m p}\right)$, ami így az adott évben fizetendő devizakamat-kiadás és az adott évi devizakamat-kiadás megelőző évi árfolyamon vett értékének különbsége. Majd ezt kifejezzük a nominális GDP arányában $\left(G D P_{t}^{n o m}\right)$. A képlet szintén a Kicsák (2017) tanulmányban is használt módszertanon alapul, azonban az adósságráta változásának hatását számszerúsítő képlethez hasonlóan itt is jelentősen egyszerüsítettük és javítottuk az ott alkalmazott képletet:

$$
e f f_{F X_{-} D}=\frac{\left(D_{t}^{F X}-D_{t}^{F X} \cdot \frac{X_{t-1}}{X_{t}}\right) \cdot I_{t}^{i m p}}{G D P_{t}^{n o m}} .
$$

\section{A hozam- és kamatváltozás hatása a kamatkiadásokra}

A fent leírt módszertan felhasználásával megállapíthatjuk, hogy az állampapírhozamok és hitelkamatok változása valamennyi vizsgált országban csökkentette az állam kamatterhét. Hazánkban a hozam- és kamatváltozás hatására 1,73 százalékponttal csökkentek a kamatkiadások a GDP százalékában a vizsgált időszakban, és ezzel a hozam- és kamatváltozás szerinti rangsorban Magyarország az első az Európai Unió tagállamai között (4. ábra). A hazai hozamok alakulását kedvezően befolyásolta a két gazdaságpolitikai ág összehangolt működése. Az önálló monetáris politika a kamatcsökkentési ciklusokkal képes volt megfelelő mértékben és tartósan leszorítani az állampapírpiaci hozamokat, továbbá az olyan célzott jegybanki intézkedések, mint az Önfinanszírozási Program az államadósság szerkezetére is kedvező hatást gyakorolt, a gazdaságösztönző költségvetési politika pedig az uniós és fejlett országok átlagát érdemben meghaladó növekedési pályára állította a hazai gazdaságot (Matolcsy - Palotai 2019). Ezenfelül a kedvező nemzetközi környezet, a nemzetközi konjunktúra, valamint a pénz- és tőkepiaci likviditásbőség is hozzájárult a hazai állampapírpiaci hozamcsökkenéshez. A kedvező hozamhatást ugyanakkor közvetett módon csökkentette a külföldi devizában denominált adósság magas ará- 
nya, ugyanis a hosszabb lejárat és a devizaadósság-kezelés szűkebb lehetőségei miatt így csak kisebb állomány árazódott át a kedvezőbb belföldi hozamszintre, míg a devizaadósság után továbbra is a magas kamatokat kellett fizetni.

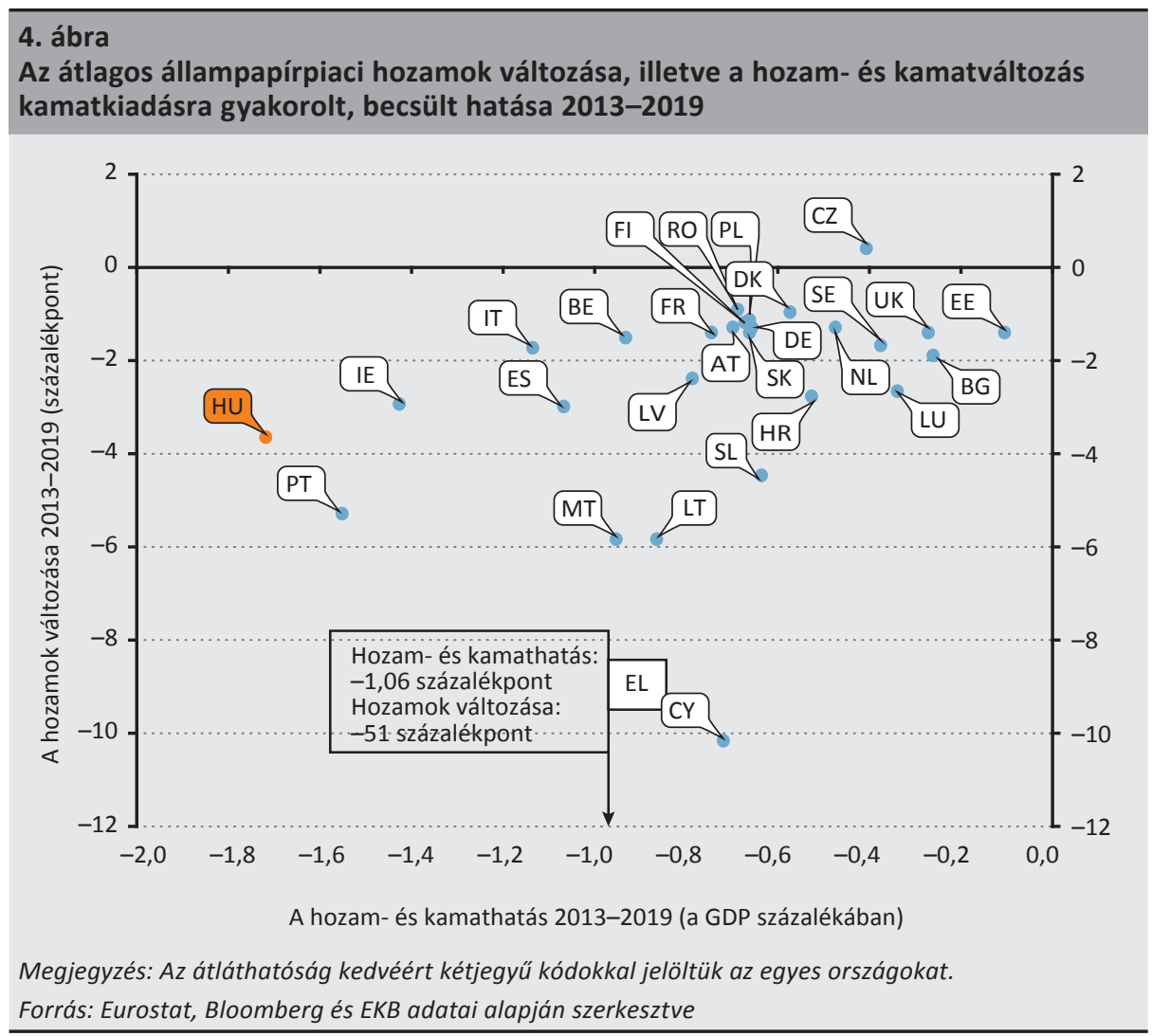

A hozam- és kamathatás számítása során nemcsak a piaci hozamok változását vettük alapul, hanem a súlyozott átlagos benchmarkhozamok változásának meghatározása után az államadósság átárazódásával is számoltunk, azzal tehát, hogy az adott hozamváltozás hatása ténylegesen mikor jelentkezik. Ezenfelül a nem piaci hitelek kamatainak változását is megkíséreltük figyelembe venni. Ezt úgy értük el, hogy első lépésben a hozamok változásának a hatását számszerűsítettük, majd ezt követően a meg nem magyarázott részből megbecsültük a fennálló hitelek, illetve EU-, IMF- és Világbank-mentőcsomagok kamathatását is. A piaci átlaghozamok és az általunk becsült hozam- és kamathatás közötti nemlineáris kapcsolat tehát több tényező figyelembevételével alakult ki (4. ábra).

A kamatkiadásokat több ország esetében is jelentősen mérsékelték a nemzetközi szervezetek által nyújtott, a piaci hozamokhoz képest lényegesen kedvezőbb kama- 
tozású mentőhitelek. Ezek a hitelek alacsony szinten fixálták a mentőcsomagban részesülő országok kamatkiadását, ezért így a radikális hozamcsökkenés éppen úgy nem jelenik meg 2013 és 2019 között a kamatkiadásokban (a 4. ábrán szemléletesen Görögország példáján látszik), mint ahogy a válság időszaka alatti (ezt az időszakot elemzésünk nem vizsgálja) kiugró hozamemelkedés hatása sem jelentkezett. Az ilyen típusú csomagok Görögország, Portugália, Írország, Spanyolország, Lettország, Ciprus és Románia 1. ábra szerinti rangsorban elfoglalt helyét is javíthatták, miközben hazánk már a vizsgált időszak kezdetén előtörlesztette a 2008-2009-ben felvett IMF-hitelét, és 2016-ban az EU felé fennálló tartozás kiegyenlítése is megtörtént. Pozíciónkat nem javította az EU-s hitel kamatfizetése sem, ugyanis a vizsgált időszak nagyobbik részében magasabb volt az EU-hitelre fizetendő fix eurokamat, mint az a kamatszint, amely hazánk számára abban az időszakban a forintpiacon elérhető volt. Az IMF-hitel előtörlesztése a kamatnyereségen felül az államadósság hátralévő futamidejének meghosszabbítását is segítette, mert az állam jórészt hosszú, 5-10 éves papírok kibocsátásából finanszírozta az egyébként 2-3 éven belül lejáró hiteleket. A mentőcsomag biztosította alacsony kamatozású hitelek következtében az államcsőd közelébe került Görögország esetében csökkentek legnagyobb mértékben a kamatkiadások 2013 és 2019 között.

\section{A segélyhitelek hatása a kamatkiadásokra}

Az IMF hitelkeretei és az Európai Unió pénzügyi stabilitási alapjai alacsony kamaton biztosítanak finanszírozási lehetőséget a külső vagy belső okokból nehéz pénzügyi helyzetbe kerülő államok számára. Erre gyakran éppen a csődkockázati felárak hirtelen emelkedése következtében megugró állampapírpiaci hozamok miatt van szükség, ugyanis a kamatkiadások emelkedése negatív spirálba sodorhatja a költségvetést. A mentőcsomagok leggyakrabban a piacon elérhetőnél jelentősen kedvezőbb kamatozású hitelkeretet jelentenek, amelyet közepes lejárattal kell visszafizetnie az adósnak. Az IMF hitelkereteihez való hozzáférés érdekében a kedvezményezett országoknak széleskörű gazdaságpolitikai vállalásokat szükséges tenniük, amelyek elsődleges célja, hogy az állam kikerüljön a finanszírozási nehézségekből, és fokozatosan képes legyen visszafizetni a kölcsönt.

Az Európai Stabilitási Mechanizmus az eurozóna tagjai számára biztosít alacsony kamatozású segélyhiteleket annak érdekében, hogy kezelje a fiskális szempontból heterogén valutaunióban fellépő finanszírozási kockázatokat, ezzel szükség esetén stabilizálva az eurozónát. Az ESM eddig öt ország számára biztosított segélyhitelt, amelyeknek köszönhetően Görögország a GDP több mint 5, Ciprus pedig közel 2 százalékának megfelelő kamatmegtakarítást tudott elérni 2016-ig (ESM 2017). Spanyolország, Írország és Portugália esetében ugyanakkor ez az érték nem érte el a GDP 1 százalékát sem. Mivel az öt állam közül Görögország volt a legsúlyosabb gazdasági válságban, megállapítható, hogy minél magasab- 
bak a csődkockázati felárral megugró piaci hozamok, annál nagyobb mértékű kamatmegtakarítás realizálható egy kedvezményes segélyhitel felhasználásával.

Magyarország az 1980-as évek óta több alkalommal igényelt a Stand-By Arrangement keretében lehívható (készenléti) hitelkeretet az IMF-től. Ezek közül a legjelentősebb a legutóbbi, 2008 novemberétől elérhető, több mint 10 milliárd SDR értékű keret volt, amely egy összesen mintegy 19 milliárd eurós, részben az Európai Unió által finanszírozott komplex hitelmegállapodás része volt. A hitelkeretet elsősorban az állampapírpiaci turbulenciák, a pénzügyi szektor instabil tőkehelyzete és a jegybanki devizatartalék alacsony szintje tették szükségessé. A teljes keretből végül 14,3 milliárd eurónyit hívott le hazánk, amit 2016 áprilisában maradéktalanul vissza is fizetett. Ezzel Magyarország törlesztett elsőként azok közül, akik finanszírozási célú válságkezelő hitelt vettek fel a 2008-2009-es válság idején. A hitel visszafizetésével csökkent az adósságon belüli devizaarány és a külföldiek tulajdoni hányada, hazánk adósságának finanszírozása pedig teljes mértékben piaci alapra került. A sérülékenység mérséklődése mellett a mérsékelt inflációs környezetben véghez vitt hazai jegybanki kamatcsökkentések és az Önfinanszírozási Program, a fegyelmezett fiskális politika, a kockázati felár csökkenése és a támogató külső környezet hatására a hazai hozamok az EU- és IMF-hitelek kamatainál is alacsonyabb szintre mérséklődtek, így még olcsóbbá vált az adósságfinanszírozás (Kicsák 2016).

Számításaink szerint a hozam- és kamathatás az országok nagy részében a GDP 0,5-1,5 százaléka körül alakul, amely csak Magyarország és Portugália esetében magasabb. A GDP 0,5 százalékánál kisebb hatást Hollandia, Csehország, Svédország, az Egyesült Királyság, Luxemburg, Bulgária és Észtország esetében tapasztaltunk. Csehországban és az Egyesült Királyságban az alacsony hatásért a kismértékü hozamcsökkenés felelős, Észtország, Luxemburg és Svédország alacsony értékeit pedig a magas nem piaci forrásbevonás magyarázza, ugyanis utóbbi két országokban mintegy 30 százalék, illetve az észteknél közel 90 százalék a hitelek aránya az adósságon belül, ami a hosszú távra fixált kamat miatt lassítja az államadósság alacsony hozamszintre történő átárazódását.

\section{Az adósságráta kamathatása}

A hozamok és kamatok változása mellett a kamatkiadásokat befolyásoló másik jelentős tényező az államadósság-ráta alakulása. Az adósságráta kamathatása lényegében több makrogazdasági folyamat összesített hatását mutatja. Itt jelenik meg ugyanis a gazdaság reálnövekedése mellett a GDP-deflátor hatása is, amelyek együtt a nominális növekedést adják. A nominális adósság változása is ezen a hatáson keresztül jelentkezik, amelyen belül fontos tényező a devizaadósság átértékelődése. A tanul- 
mányban az ezeket a folyamatokat együttesen megragadó adósságráta változását, illetve annak kamatkiadásokra gyakorolt hatását vizsgáljuk, mert az államadósságot mérő legfontosabb mutató a (például az EU-s költségvetési szabályokban is szereplő) GDP-arányos adósságráta, amely az ország kibocsátásához viszonyítja annak eladósodottságát.

A vizsgált időszakban csökkent az uniós országok eladósodottsága, a tagországok súlyozott átlagával számolt GDP-arányos államadósság ugyanis 86 százalékot meghaladó szintröl 79 százalék közelébe mérséklödött és a 28 országból 23-ban csökkent az államadósság. A hazai adósságráta a 2011 óta tartó folyamatos csökkenésnek köszönhetően 2019 végén mintegy 13 százalékponttal az EU-átlag alatt alakult. Ezzel az EU-ban a középmezőnyben helyezkedik el hazánk az adósságráta nagyságát illetően. Régiós összevetésben a horvát adósságszinttől elmarad a hazai mutató, míg a szlovén, szlovák, lengyel, román, cseh szintet meghaladja (5. ábra).

A görög, az olasz és a portugál államadósság érdemben a GDP 100 százaléka felett alakult, Görögországban a 175 százalékot is meghaladva. Ezzel szemben Luxemburgban és Bulgáriában mindössze 20 százalék körüli az államadósság szintje, a legalacsonyabb adósságszinttel rendelkező Észtországban pedig a GDP mintegy 8 százalékát teszi ki az adósság.

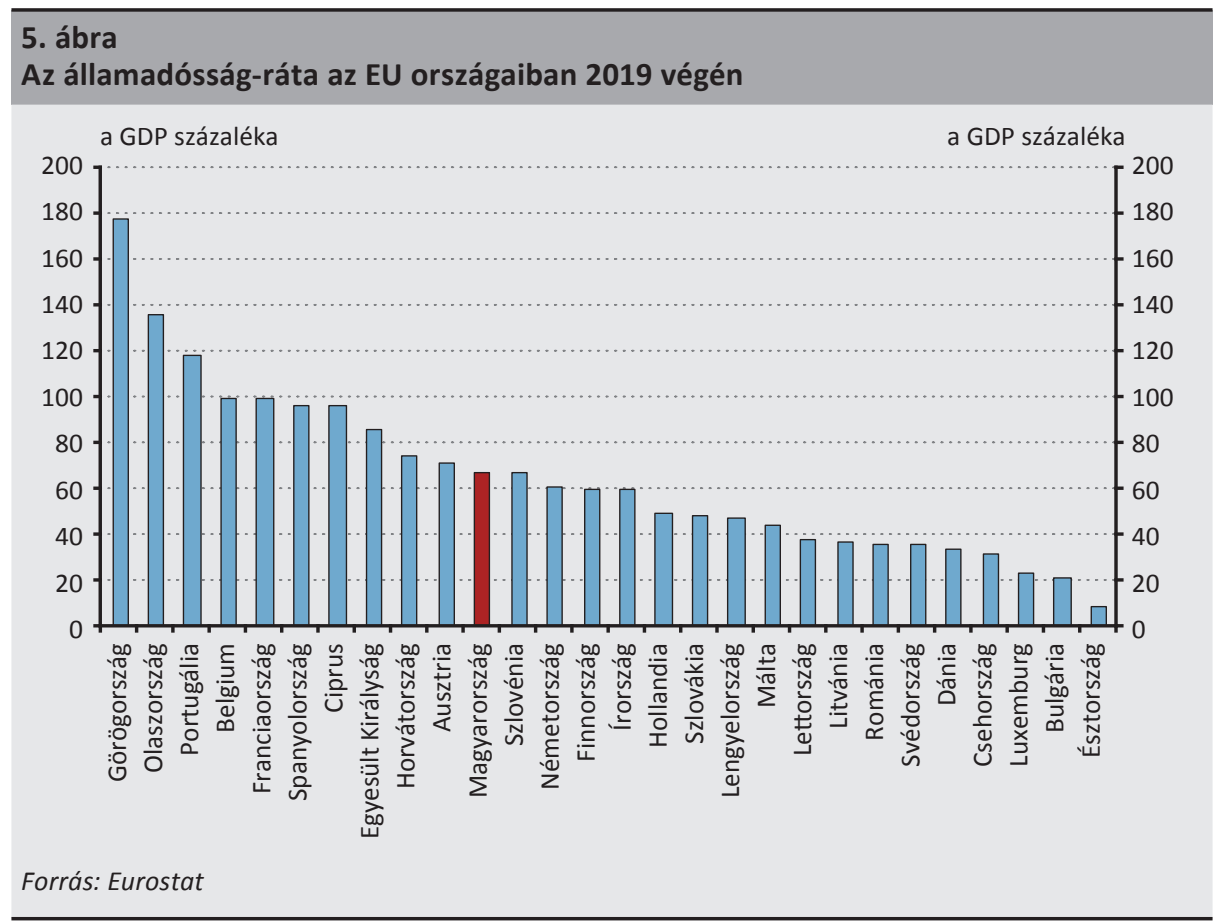


Becslésünk szerint az adósságcsökkenés hatására 0,4 százalékponttal mérséklődtek a kamatkiadások Magyarországon, ami az EU-n belül egyedülálló módon, 2011 óta folyamatosan tartó adósságcsökkenés következménye. A legjelentősebb mértékű adósságcsökkenés a vizsgált időszakban Írországban, valamint Máltán volt (6. ábra). Az adósságráta kamatkiadásokra gyakorolt hatásának becslésekor főként az államadósság változását vettük figyelembe, amely változáshoz képest csak kismértékú, például az adósság éven belüli gyors növekedését vagy csökkenését, valamint az átlagos hátralévő futamidő változását figyelembe vevő korrekciót alkalmaztunk. Ennek következtében az adósságráta kamathatása a felhasznált mögöttes változó, azaz az adósságráta változásával erős kapcsolatot mutat (6. ábra).

\section{6. ábra \\ Az adósságráta változása és az adósság változásának hatása a kamatkiadásokra 2013-2019}

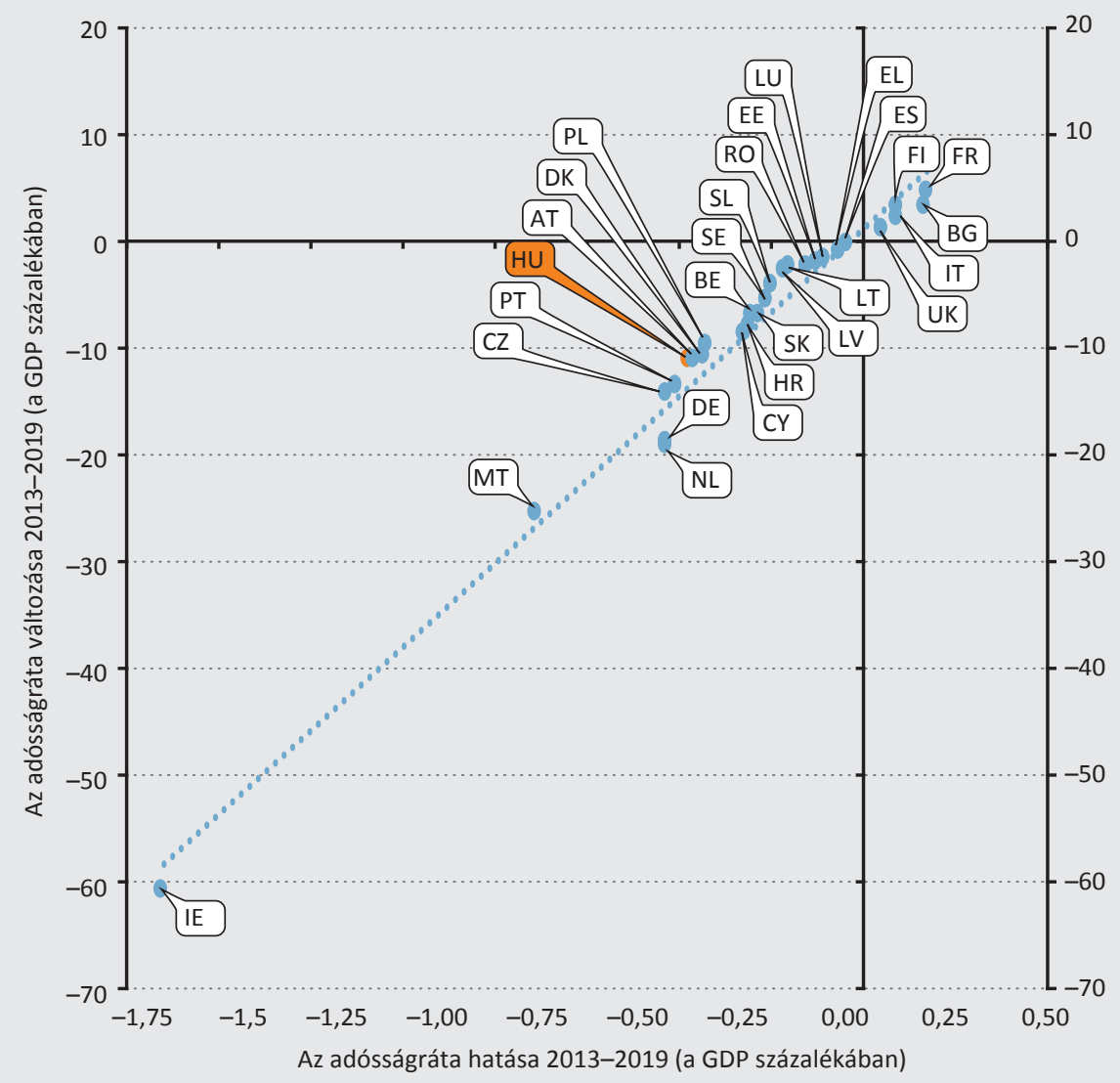

Megjegyzés: Az átláthatóság kedvéért kétjegyű kódokkal jelöltük az egyes országokat.

Forrás: Eurostat, Bloomberg és EKB adatai alapján szerkesztve 
Az államadósság-ráta hatását tekintve hazánk a hetedik helyen található. Összesen 23 olyan ország van, ahol kamatkiadásokat csökkentő adóssághatást tapasztaltunk a vizsgált időtávon, miközben az adósságráta hatása a GDP -0,5 és $+0,5$ százaléka között szóródik, az első két országot leszámítva. Kamatkiadást növelő hatás 5 ország esetében jelentkezik, de a hozam- és kamatcsökkenés ezen országokban is ellensúlyozta a kiadásnövekedést, tehát a kamatfizetés végeredményben ott sem növekedett.

Az adósságráta csökkenéséhez több országban a magas gazdasági növekedés járult hozzá. Különösen jelentős volt ez a hatás Írországban és Máltán, aminek következtében az adósságráta e két országban csökkent a legnagyobb mértékben. Más országokban, például Németország és Hollandia esetében nem elsősorban a gazdasági növekedés okozta az adósságráta ilyen ütemú javulását, hanem a fegyelmezett költségvetési politika által eredményezett költségvetési többlet, ami a nominális adósság növekedésének visszafogásához vezetett.

\section{A devizaadósság hatása a kamatkiadásokra}

A devizaadósság kamatkiadásokra gyakorolt hatása összességében igen mérsékelt, és a devizaadósság átértékelődésétől - ami az adósságráta hatásában található meg - külön kezelendő, itt ugyanis az adott deviza-kamatfizetés hazai devizában kifejezett értékének változása kerül fókuszba. Ez a közvetlen hatás Magyarország esetében tehát azt jelenti, hogy a fix deviza-kamatfizetés értéke hogyan alakult forintértéken.

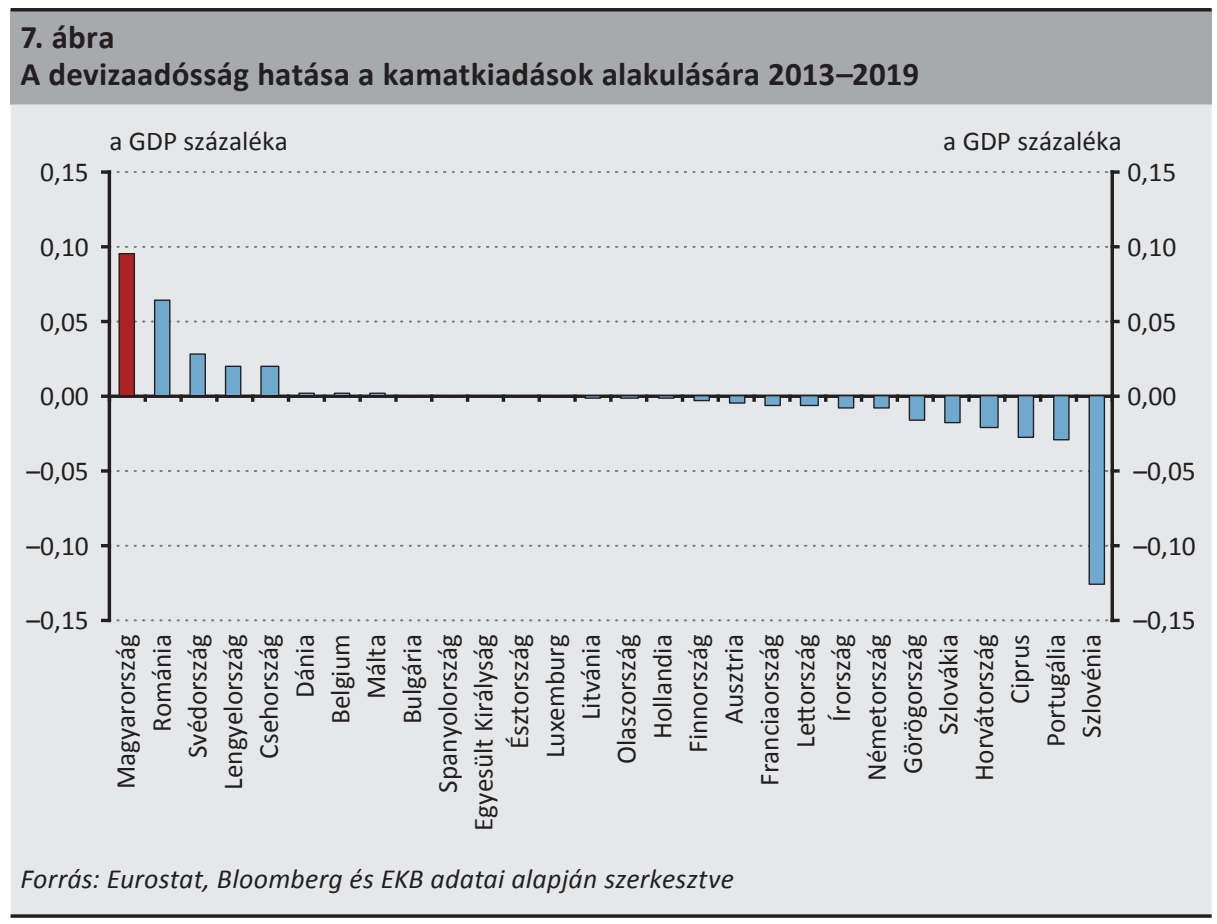


A devizaadósság kamathatása mintegy 0,1 százalékponttal emelte a kamatkiadásokat Magyarországon, ami a legnagyobb addicionális kamatteher-növekedés az EU-ban. A 7. ábrán látható, hogy a közép-kelet-európai régió több államában is jelentkezik ez a hatás, ugyanis a rangsorban közvetlenül hazánk után Románia, valamint nem sokkal később Lengyelország és Csehország következik. Több tagállam, különösen az eurozónában, kizárólag a közös devizában adósodott el, így ezekben az esetekben a devizaadósság kamathatása értelemszerűen nulla. Kiadáscsökkentő hatásról azokban az országokban beszélhetünk, ahol a hazai deviza erősödött ahhoz a pénznemhez képest, amelyben az eladósodás történt.

A régiós országokat meghaladó magas hazai devizahatás fó oka, hogy Magyarországon 2019-ben a negyedik legmagasabb volt a GDP-arányos devizaadósság az Európai Unió tagállamai között (8. ábra). A magyarnál magasabb devizaadóssággal rendelkező EU-s országokban ugyanakkor lényegesen kötöttebb az árfolyamrendszer. Horvátországban és Romániában az euróhoz képest szűk sávban mozog az árfolyam (stabilized arrangement), a még kötöttebb bolgár rezsimben pedig valutatanács (currency board) müködik, szemben a magyar lebegő (floating) árfolyamrendszerrel (IMF 2020).

\section{8. ábra}

GDP-arányos devizaadósság az Európai Unió tagországaiban 2019-ben

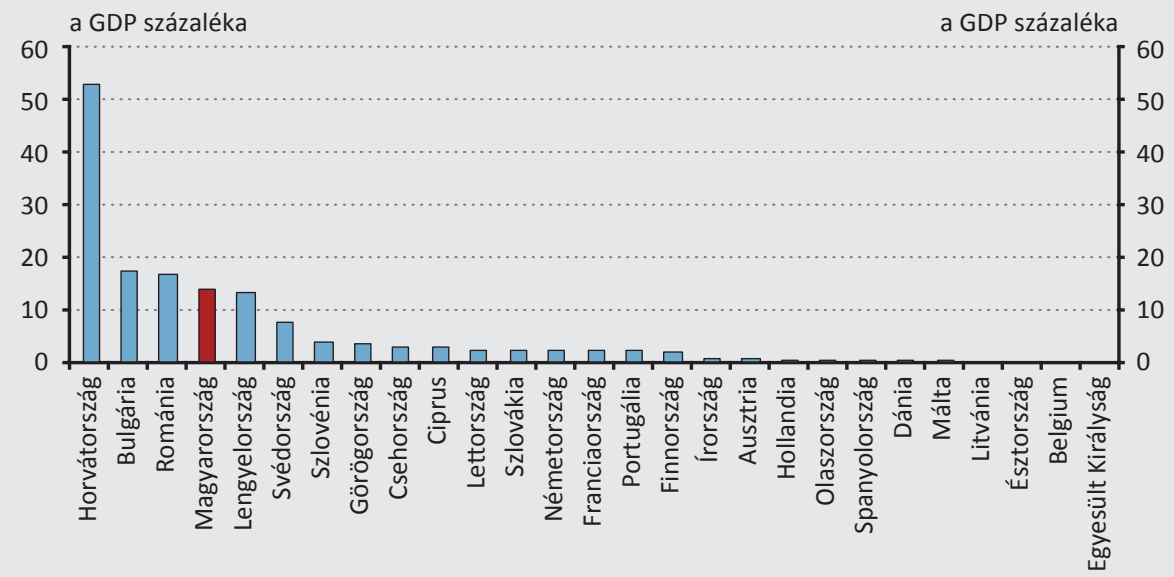




\section{Az eurozónához való csatlakozás hatása az adósság devizaarányára}

A devizaadósság arányát mutató idősorokon több országnál jelentős mértékű visszaesést láthatunk az eurozónához való csatlakozás évében. Ennek oka, hogy a valutaunióhoz csatlakozó országok devizaadóssága elsősorban euróban volt denominálva a zónatagságot megelőző években. A csatlakozást követő visszaesés elsősorban a magasabb devizaaránnyal rendelkező balti országok esetében volt kimagasló (60-80 százalékpont), de Ciprus és Szlovénia esetében is 20-30 százaléknyi devizaadósság csökkent nulla közelébe. A dollárban, svájci frankban, jenben vagy más devizában fennálló adósság természetesen az euro bevezetése után is devizaadósság marad.

Egy eurozóna-tagállamnak ugyanakkor nem áll rendelkezésére olyan független monetáris politikai eszköztár, mint a korábbi, saját pénzneme esetében. A 2008as világgazdasági válságból kibontakozó eurozóna-válság a déli europeriféria államainak (Görögország, Portugália, Olaszország, Spanyolország) esetében megmutatta, hogy a heterogén és az önálló monetáris politikától megfosztott, de közös fiskális politikával nem rendelkező, ennélfogva szuboptimális valutaövezet okozta finanszírozási nehézségek ellensúlyozhatják a devizaadósság leépítéséből fakadó előnyöket (Benkö 2013).

\section{8. Összefoglalás}

Tanulmányunkban a magyar költségvetés eredményszemléletű kamatkiadásainak alakulását vizsgáltuk az Európai Unió kontextusában. A vizsgálat keretét egy olyan dekompozíciós módszer adta, amellyel a kamatkiadások változása tényezőkre bontható, és a felbontás segítségével megállapítható, hogy milyen hatások, illetve makrogazdasági folyamatok vezettek a kiadáscsökkenéshez. Ezen felül a tényezők mögöttes változókkal való kapcsolatát is megvizsgáltuk.

Az Európai Unió országai közül 2013 és 2019 között Magyarországon mérséklődtek a második legnagyobb, a GDP 2,2 százalékának megfelelő mértékben a kamatkiadások. Bár az államadósság kamatterhei valamennyi uniós országban csökkentek, a hazainál nagyobb mértékű megtakarítás csak Írországban keletkezett. A teljes kamatmegtakarítás a vizsgált időszak alatt a GDP 9 százalékát tette ki Magyarországon. Ez a jelentős mértékű megtakarítás a többletes elsődleges egyenleggel együtt pozitív adósságspirált hozott létre: a kamatkiadások csökkenése hozzájárult az adósságráta mérséklődéséhez, a csökkenő adósság pedig tovább mérsékelte a kamatkiadásokat.

A kamatkiadások változásának tényezőkre bontása megmutatja, hogy a hozam- és kamathatás az Európai Unión belül hazánkban a legnagyobb (a GDP-arányában 1,73 százalék), és önmagában mintegy 80 százalékban járult hozzá a kiadáscsökkenés- 
hez. Az erőteljes hozamcsökkenés az alacsony inflációs környezetben bevezetett jegybanki intézkedéseknek (kamatcsökkentési ciklus, Önfinanszírozási Program, jegybanki eszköztár átalakítása) köszönhetően valósulhatott meg, amelyet a hazai makrogazdasági folyamatok, a fegyelmezett költségvetési politika, valamint a nemzetközi környezet is támogatott.

Az adósságráta csökkenése a GDP 0,4 százalékát elérő mérséklődést magyaráz a kamatkiadás-csökkenésből, amellyel Magyarország a hetedik helyen áll az uniós rangsorban, és mintegy 18 százalékát eredményezi a teljes kiadáscsökkenésnek. A mérséklődés elsősorban annak köszönhető, hogy 2011 óta folyamatosan csökken a hazai adósságráta. A folyamatos csökkenés következtében a hazai adósságszint az EU-átlagnál mintegy 13 százalékponttal alacsonyabb volt 2019-ben. Az adósságráta változása önmagában 23 országban csökkentette, 5 tagállamban pedig növelte a kamatkiadást a vizsgált időszakban. Összességében ugyanakkor ott sem emelkedett a kamatkiadás, ahol az adósság nőtt, ezekben az esetekben ugyanis a hozamcsökkenés ellensúlyozta az eladósodás kedvezőtlen hatását.

A devizaadósság kamathatása valamennyi vizsgált országban alacsony mértékú. Magyarországon a devizaadósság önmagában 0,1 százalékos addicionális kamatteher-növekedést okozott, tehát alacsonyabb devizaadósság-szint mellett kissé magasabb kamatmegtakarítást is el lehetett volna érni. Számos eurozóna-tagországban nincsen, vagy elhanyagolható méretű a devizaadósság állománya, így ezekben az országokban nem jelentkezett ilyen hatás.

Összefoglalásképpen elmondhatjuk, hogy a hazai kamatkiadások uniós összevetésben is jelentős csökkenésében domináns szerepe volt az állampapírpiaci hozamok mérséklődésének, amit a gazdaságpolitika két fő ágának számító költségvetési és monetáris politika összhangja tett lehetővé. Az adósságráta 2011 óta folyamatosan csökkenő trendje szintén hozzájárult a kamatkiadások mérséklődéséhez, amit csak kismértékben fogott vissza a devizaadósság kedvezőtlen hatása.

\section{Felhasznált irodalom}

Baksay Gergely - Karvalits Ferenc - Kuti Zsolt (2012): The impact of public debt on foreign exchange reserves and central bank profitability: the case of Hungary. BIS Papers, No 67: 179-193. https://www.bis.org/publ/bppdf/bispap67l.pdf

Baksay Gergely - Berki Tamás - Csaba Iván - Hudák Emese - Kiss Tamás - Lakos Gergely - Lovas Zsolt - P. Kiss Gábor (2013): Az államadósság alakulása 1998 és 2012 között Magyarországon: trendek, okok, hatások, MNB-Szemle, 2013(Különszám): 14-22. https:// www.mnb.hu/letoltes/baksay.pdf

Benkő Dávid János (2013): A Merkel-kormány válságkezelése a német belpolitika tükrében. BA/BSc szakdolgozat, BCE Nemzetközi Tanulmányok Intézet, Budapesti Corvinus Egyetem. 
Blanchard, O. (1990): The Sustainability of Fiscal Policy: New Answers to An Old Question. OECD Economic Studies, 15(Autumn): 7-36.

Bundesbank (2017): The development of government interest expenditure in Germany and other euro-area countries. Monthly Report, July, Deutsche Bundesbank.

Csutiné Baranyai Judit - Lehmann Kristóf - Mérő Balázs (2017): Új vizeken az EKB - „Whatever it takes"? In: Lehmann Kristóf - Palotai Dániel - Virág Barnabás (szerk.): A magyar út célzott jegybanki politika. A Magyar Nemzeti Bank könyvsorozata, Magyar Nemzeti Bank.

Das, U.S. - Papapioannou, M. - Pedras, G. - Ahmed, F. - Surti, J. (2010): Managing Public Debt and Its Financial Stability Implications. IMF Working Paper WP/10/280, International Monetary Fund. https://doi.org/10.5089/9781455210879.001

ESM (2017): Evaluation Report. EFSF/ESM Financial Assistance, European Stability Mechanism. https://www.esm.europa.eu/sites/default/files/ti_pubpdf_dw0616055enn_ pdfweb_20170607111409_0.pdf. Letöltés ideje: 2020. április 6.

Guscina, A. (2008): Impact of Macroeconomic, Political, and Institutional Factors on the Structure of Government Debt in Emerging Market Countries. IMF Working Paper WP/08/205, International Monetary Fund. https://doi.org/10.5089/9781451870633.001

Hemming, R. - Petrie, M. (2000): A Framework for Assessing Fiscal Vulnerability. IMF Working Paper WP/00/52, International Monetary Fund. https://doi. org/10.5089/9781451847246.001

IMF (2020): Annual Report on Exchange Arrangements and Exchange Restrictions 2019. International Monetary Fund, Washington, DC. https://www.imf.org/en/ Publications/Annual-Report-on-Exchange-Arrangements-and-Exchange-Restrictions/ Issues/2020/08/10/Annual-Report-on-Exchange-Arrangements-and-ExchangeRestrictions-2019-47102

Izák, V. (2009): Primary balance, public debt and fiscal variables in postsocialist members of the European Union. Prague Economic Papers, 18(2): 114-130. https://doi.org/10.18267/j. pep.345

Kicsák Gergely (2015): A 2012-2015-ben bevezetett jegybanki intézkedések hatása az államháztartás finanszírozására. Szakmai cikk, Magyar Nemzeti Bank. https://www.mnb. hu/letoltes/15-06-29-kicsak-gergely-a-2012-2015-ben-bevezett-jegybanki-intezkedesekhatasa-az-allamhaztartas-finanszirozasara.pdf. Letöltés ideje: 2020. március 6.

Kicsák Gergely (2016): Az EU-hitel utolsó részletének törlesztése egyszerre csökkentette az ország sérülékenységét és az adósságfinanszírozás költségét. Szakmai cikk, Magyar Nemzeti Bank. https://www.mnb.hu/letoltes/kicsak-az-eu-hitel-utolso-reszletenekvisszafizetesemnbhonlapra.pdf. Letöltés ideje: 2020. március 6. 
Kicsák Gergely (2017): Az állami kamatkiadások alakulása Magyarországon 2000-2015. Hitelintézeti Szemle, 16(1): 46-73. https://hitelintezetiszemle.mnb.hu/letoltes/kicsakgergely.pdf

Lentner Csaba (2015): Az új magyar állampénzügyi rendszer - történeti, intézményi és tudományos összefüggésekben. Pénzügyi Szemle, 60(4): 458-472.

Matolcsy György (2019): A sikeres válságkezelés a 12 gazdasági fordulat tükrében. Polgári Szemle, 15(1-3): 15-45. https://doi.org/10.24307/psz.2019.0903

Matolcsy György - Palotai Dániel (2018): A magyar modell: A válságkezelés magyar receptje a mediterrán út tükrében. Hitelintézeti Szemle, 17(2): 5-42. http://doi.org/10.25201/ HSZ.17.2.542

Matolcsy György - Palotai Dániel (2019): Felzárkózási pályán Magyarország. Hitelintézeti Szemle, 18(3): 5-28. http://doi.org/10.25201/HSZ.18.3.528

Panizza, U. (2008): Domestic and External Public Debt in Developing Countries. United Nations Conference on Trade and Development Discussion Paper No. 188. https://doi. org/10.2139/ssrn.1147669

Tóth G. Csaba (2011): Adósságdinamika és fenntarthatóság. Statisztikai Szemle, 89(12): 1242-1268.

Tóth G. Csaba (2014): A költségvetés fenntarthatóságát mérő mutatók elörejelző képessége. Pénzügyi Szemle 2014(4): 544-561.

Turner, D. - Spinelli, F. (2012): Interest-rate-growth differentials and government debt dynamics. OECD Journal: Economic Studies, 2012(1): 103-122. http://dx.doi.org/10.1787/ eco_studies-2012-5k912k0zkhf8 


\section{Melléklet}

\section{1. táblázat}

A kamatkiadások változásának szerkezete 2013-2019 között (GDP százalékában)

\begin{tabular}{|c|c|c|c|c|c|}
\hline & $\begin{array}{c}\text { Hozam- és } \\
\text { kamatváltozás } \\
\text { hatása }\end{array}$ & $\begin{array}{c}\text { Adósságráta } \\
\text { változásának } \\
\text { hatása }\end{array}$ & $\begin{array}{c}\text { Devizaadósság } \\
\text { kamathatása }\end{array}$ & Egyéb hatások & $\begin{array}{c}\text { Kamatkiadások } \\
\text { változása }\end{array}$ \\
\hline Írország & $-1,43$ & $-1,66$ & $-0,02$ & 0,11 & $-3,00$ \\
\hline Magyarország & $-1,73$ & $-0,40$ & 0,09 & $-0,15$ & $-2,20$ \\
\hline Portugália & $-1,56$ & $-0,43$ & $-0,05$ & 0,24 & $-1,80$ \\
\hline Málta & $-0,95$ & $-0,77$ & 0,00 & 0,22 & $-1,50$ \\
\hline Olaszország & $-1,14$ & 0,10 & 0,00 & $-0,36$ & $-1,40$ \\
\hline Belgium & $-0,92$ & $-0,25$ & 0,00 & $-0,13$ & $-1,30$ \\
\hline Ausztria & $-0,68$ & $-0,39$ & $-0,01$ & $-0,12$ & $-1,20$ \\
\hline Spanyolország & $-1,06$ & $-0,02$ & 0,00 & $-0,12$ & $-1,20$ \\
\hline Görögország & $-1,06$ & $-0,04$ & $-0,02$ & $-0,08$ & $-1,20$ \\
\hline Lengyelország & $-0,65$ & $-0,36$ & 0,02 & $-0,11$ & $-1,10$ \\
\hline Németország & $-0,64$ & $-0,45$ & $-0,01$ & 0,11 & $-1,00$ \\
\hline Dánia & $-0,56$ & $-0,37$ & 0,00 & $-0,07$ & $-1,00$ \\
\hline Litvánia & $-0,85$ & $-0,16$ & 0,00 & 0,11 & $-0,90$ \\
\hline Franciaország & $-0,73$ & 0,10 & $-0,01$ & $-0,26$ & $-0,90$ \\
\hline Horvátország & $-0,51$ & $-0,26$ & $-0,04$ & $-0,09$ & $-0,90$ \\
\hline Ciprus & $-0,71$ & $-0,27$ & $-0,03$ & 0,11 & $-0,90$ \\
\hline Lettország & $-0,78$ & $-0,17$ & $-0,01$ & 0,16 & $-0,80$ \\
\hline Hollandia & $-0,46$ & $-0,46$ & 0,00 & 0,12 & $-0,80$ \\
\hline Szlovénia & $-0,62$ & $-0,20$ & $-0,14$ & 0,16 & $-0,80$ \\
\hline Szlovákia & $-0,65$ & $-0,24$ & $-0,02$ & 0,21 & $-0,70$ \\
\hline Románia & $-0,68$ & $-0,12$ & 0,05 & 0,14 & $-0,60$ \\
\hline Csehország & $-0,39$ & $-0,45$ & 0,01 & 0,24 & $-0,60$ \\
\hline Egyesült Királyság & $-0,42$ & 0,06 & 0,00 & $-0,24$ & $-0,60$ \\
\hline Finnország & $-0,66$ & 0,16 & 0,00 & 0,10 & $-0,40$ \\
\hline Svédország & $-0,36$ & $-0,22$ & 0,03 & 0,14 & $-0,40$ \\
\hline Luxemburg & $-0,39$ & $-0,08$ & 0,00 & $-0,04$ & $-0,30$ \\
\hline Észtország & $-0,08$ & $-0,10$ & 0,00 & 0,08 & $-0,10$ \\
\hline Bulgária & $-0,24$ & 0,17 & 0,00 & $-0,03$ & $-0,10$ \\
\hline
\end{tabular}

Forrás: Eurostat, Bloomberg és EKB és adatai alapján szerkesztve 